\title{
Application Cases of Main Tourist Destination Competitiveness Models in Different Countries of the World, Especially in Balkan Region Destinations.
}

\author{
Sonila Berdo \\ Institution/Affilation: University Pavaresia Vlore \\ sonila.berdo@unipavaresia.edu.al
}

\begin{abstract}
The aim of this paper is to bring into consideration and describe the application of some of the main tourist destination competitiveness models implemented in different countries of the world and especially in Balkan region destinations. Destinations like Croatia, Romania, Bulgaria, Italia, Slovenia and some other wellknown like Taiwan, Caribbean islands and Sinaloe-Mexico are included in this study. The above cases are part of a literature review process related to this topic. These cases highlight the technical profile of the models and do contribute to facilitate the selection and implementation process of the appropriate model in similar countries or destinations not yet implemented. Different researchers of the field may provide a good understanding of the current tourism competitiveness situation in the regions here included and also of the way tourism competitiveness models needs to adapt to the study objectives and specific circumtainces of each case/ destination.
\end{abstract}

Keywords: Tourism competitiveness, tourist destinations, competitiveness models.

\section{Introduction}

There are different tourism destination evaluation models available and different circumstances that limit the applicability of them. In this reviewing article may be find different situations, where these models are applied and how they are applied. Here, the destinations are chosen by taking in consideration their geographical position similarities and particularities from island to continental geo-position, from europian to exotic destinations; and their political history, from western countries to former socialist countries.

\subsection{Slovenia Case}

To analyze the competitiveness of Slovenia as a tourist destination as well as its competitive advantages, Gomezelj and Mihalic (2008) applied two different models, respectively, De Keyser \& Vanhove model and the integrated model of Dwyer \& Kim. Referring to these two models, the study aimed to identify individual determinants and competitive indicators perceived as such by the Slovenian tourism experts.

According to De Keyser-Vanhove model, there are five factors that do affect the competitiveness of the destination, as follows: the tourism policy, macroeconomics, supply, transportation and demand factor. While according to the integrated model of Dwyer and Kim (2003), the determining factors are grouped into six categories, respectively, the inherited resources, created resources, the supporting factors, the destination management, the tourism demand and situational conditions.

The analysis was conducted through 291 questionnaires addressed to government officials, managers of travel agencies, managers of the hospitality sector, tourism high school academics, managers of tourist services, post-graduate tourism courses students, and local tourism organizations employers. Also, the analysis involved a total of 85 indicators (attributes) and the responses of each of the individuals surveyed were grouped in each of six categories of Dwyer \& Kim Integrated model. The processing of data collected through the questionnaire instrument resulted in the following situations: Regaring ot the Inherited resources group, the highest ranking position was given to the attributes like: the nature of undiscovered flora and fauna, climate, traditional arts, the destination cleanness, national parks, heritage, artistic and architectural features and historical sites. In the created resources group factor attributes like: resorts and health/spa, visitors accessibility to natural areas, culinary abilities, casinos, outdoor activities, accommodation, easy access to food services, rural tourism, sports, winter activities, the existence of special programs for visitors, guides and information to tourists, special events/festivals, recreation, aquatic activities, efficiency and quality of local transport, efficiency and quality of the 
airport, nightlife, community support to special events and amusement parks, have been identified as the most competitive factors of Slovenia.

In the Supporting Factors group, individuals ranked as most competitive factors as follows: residents hospitality, communication and confidence between tourists and residents, telecommunications system, the quality of tourist services and financial institutions facilities, and exchange rates offices availability. While as the less competitive attributes, they ranked variables like as: the customs office efficiency, visa legal requirements, health services to tourists and animation activities. In the Destination Management group, tourists prioritized factors in the order as follows: residents support to the tourism development, the evaluation importance of service quality, private sector awareness of the sustainable tourism development importance, good entrepreneurial skills of tourism local businesses, destination's vision reflecting the tourists' values, tourism services quality, the destination's vision reflecting community values, employees education in tourism sector, the destination's vision reflecting the tourism experts values, development and promotion of new tourist products, existence of appropriate tourism education programs, the cooperation between firms, private and public sector engagement in tourism industry, public awareness to the sustainable tourism development importance, governmental cooperation in tourism development policy and the level of foreign investment in the tourism industry. In the Situational Conditions group, individuals prioritized factors in the order as follows: the security and visitors protection, political stability, worth of money to the tourist experiences in destination, worth of money to the accommodation, the characteristics of shopping, the use of IT by firms, the managers skills, the use of e-commerce, investment environment and cooperation between public and private sectors, are regarded as factors that make Slovenia as very competitive destination. In terms of Tourism Demand group, the general image of the destination, the compatibility between the destination's products and tourists' preferences, international awareness of destination and its products, are the main attributes identified and ranked according to their importance in the destination competitiveness profile.

\subsection{Slovenia and Croatia frontier area Case}

Vodeb (2012) assessed the tourism competitiveness of seven tourist destinations located in the cross-border area between Croatia and Slovenia. This study aimed to identify the variables that affected the cross-border cooperation. The study used Calgary model of destination competitiveness developed by Crouch and Ritchie (1993). Providers of tourism products had to evaluate from 1 point to 5 points competitiveness factors according to Calgary model and labeled as: destination attraction, destination management, the organization, and information and destination efficiency. This study used factor analysis and its relevant tests to examine the sufficiency or adequacy of samples and data. Using factor analysis, it was reduced a large number of variables to a smaller number, called factors. The factors identified in this case were as follows: cooperation and integrated tourism supply, residents, destination competitiveness evaluation and functions of the tourist destinations organizations.

By the implementation of Calgary model of evaluating the destinations competitiveness for both countries, Croatia and Slovenia, resulted that the highest average value was for attributes like destination attraction and less evaluated for efficiency, management, information and organization.

\subsection{Romania Case}

Bobirca (2006) in her study was focused on identifying the factors that determine significantly the competitive and comparative advantages of the tourist destination of Romania. For this purpose, the author used Porter's Diamond model to identify the competitive advantages of national tourism of Romania in each of the four determinant factors proposed by Porter (1990) strategy, structure and rivalry of firms; demand conditions; related and supporting industries; governmental role and factor conditions. The empirical results by application of the Porter's model showed that in the factor conditions, Romania has a competitive advantage and on the following elements: geographical position, large variety of tourist products, low labor cost, positive attitude toward tourism. For the second factor that of demand conditions, have been identified as important these elements: large population, the low purchasing power of domestic demand, falling demand for resorts on the coast, and the increasing sophistication of domestic demand. About the third factor, that of related and supporting industries, the authors identified the following elements: Poor distribution and promotion networks, but still developing, low degree of coordination and clustering. Finally, about strategy, structure and competition, the authors 
evaluated as important elements of the recent privatization, the low level of competition outside the main cities, the support of the weak, but improving, government, weak managerial skills and marketing.

The author concluded that as part of the strategy to promote Romania as a tourist destination, a special importance should be given to improving the quality of tourism infrastructure, research and development, sustainable development, human resources and skills development managerial and marketing, as well as international cooperation.

\subsection{Romania and Bulgaria Case}

Croitoru (2011) analyzed the destination competitiveness index (TCl) of two tourist destinations, respectively Romania and Bulgaria. TCl aims to assess the elements that ensure the development of the tourism sector in different countries through three categories of variables that affect the global tourism competitiveness, known as: (1) the policy rules and regulations; (2) business environment and infrastructure; (3) cultural, human and natural resources, each of which includes a number of factors that determine the fundamental elements in tourism competitiveness analysis. The set of data used to assess these factors, included data obtained from annual surveys conducted by the World Economic Forum and quantitative data obtained from available public sources, international institutions and organizations, and tourism experts.

In this study it is analyzed only one of the indicators of the $\mathrm{TCl}$, regulatory framework and there are evaluated only two of its five elements: the rules and regulations politics and environmental sustainability.

About the first element, Romania had a better ranking position than Bulgaria, especially in property rights, legislation impact on FDI, bilateral agreements on air services, the start time to open a new business and deals of GATS type. While related to transparency of government decisions and costs level to start a business, Romania was ranked not in a good position compared to Bulgaria.

About the second element that of environmental sustainability, Romania proved to be more competitive in applying the environmental protecting rules, in the tourism sector development, the emission level of dioxide carbon, in the environmental protection regulation, while it was less competitive than Bulgaria regarding the ratification of environmental protection agreements.

\subsection{Former Socialist Countries}

Papp and Raffay (2011) aiming to study the factors that had effected the tourism competitiveness of the former socialist countries used the Pyramid model developed by Lengyel (2004). The Pyramid model was adapted to the former socialist countries (Hungary, Poland, Bulgaria and Romania) by combining elements of Crouch and Ritchie (2003) and Dwyer et al. (2004) destination competitiveness models and Lengyel model of regions competitiveness.

In the bottom part of the pyramid (first level) which constitutes the base of the pyramid, and does represent competitive potentiality, there are included mainly sustainable elements which turned the post-socialist countries in attractive destinations for visitors. Natural heritage, location and accessibility, innovation, cultural heritage, mentality, openness and hospitality, and climate are important factors, which constitute the competitive potentiality of these destinations.

At the second level of the pyramid are included the development factors, which are ex ante factors such as human resources, infrastructure, tourist services, the management of destinations and attractions development. These factors needs to be developed further so they can ensure their direct impact on the competitive position (basic categories), which constitutes the third level of the pyramid. In this last level there are included ex post factors like as income level, labor productivity and employment level.

\subsection{Taiwan Case}

Wang et al. (2008) applied the destination competitiveness model developed by Crouch and Ritchie (Crouch and Ritchie, 1999; Richie and Crouch, 1993, 2000, 2003), to analyze the competitiveness of four tourist destinations in Taiwan. 
Crouch and Ritchie (1999) defined a conceptual model of tourist destinations competitiveness, based on the model of Porter (1990) of national competitive advantages. Their model identifies two specific interrelated environments called micro and macro. Micro and macro environment affects the competitiveness of a destination through four main components: basic resources; and supporting factors and resources; destination management and qualifying determinants.

The study was conducted in 2006, through questionnaires, in which tourists should rank attributes for each category of tourist destinations competitiveness. From a total of 400 questionnaires were completed only 386 .

The authors in this study estimated the average value and the ajusted value for each category. Results of the attributes analysis showed that none of the four tourist cities in Taiwan demonstrated to be a dominant destination compared with three other competing destinations, in any of the four components proposed by Crouch and Ritchie model.

\subsection{Caribbean Islands Case}

Chambers (2010) analyzed and tried to identify the characteristics, experiences and strategies that hotels and all-inclusive resorts use to differentiate from the characteristics/ attributes of the other part of their particular island and the Caribbean region in general, viewed from the managers and experts' perspective of all-inclusive hotels included in the survey.

The study used several primary and secondary data. Primary data were collected using a quantitative method, in the form of a survey addressed to managers of all-inclusive hotels, registered also as members of hotel and tourism association. Secondary data were obtained from sources such as statistical bulletins, materials provided by travel agencies, books, tourist magazines, and websites.

In this study there were distributed 220 questionnaires, but only 12 of them filled, and identified 7 tourist destinations as the most distinguished from a total of 15 destinations (the islands of the Caribbean region).

The results of survey showed that the reputation of the island where the resort is located, food, employees, hotel ranting, leisure activities and accommodation are some of the distinctive features that helps to differentiate all-inclusive hotels in various destinations within the Caribbean region. Also, features like employees, service and goodwill are factors that influence the decision of a tourist to choose an all-inclusive hotel in the Caribbean islands.

Visitors hospitality and natural attractions of the destination are considered as the most important characteristics that differentiate destinations of Caribbean islands, while facilities to enter the country, distance and travel time to the destination, quality accommodation, sicurity and safety and climate destination, have been identified as factors that do have a less impact to differentiate destinations from each other.

The natural beauty of the destination, a favorable climate, the good reputation of domestic food, sicurity and safety, easy entering procedures to the country, the residents hospitality, are distinguishing characteristics that influence the decision of a tourist to choose a destination within the Caribbean region. On the other hand, cultural attractions, shopping, nightlife, special events / festivals and travel distance and time travel to destination are attributes that have a lesser impact on the choices of tourists.

\subsection{Italy Case}

Cracolici and Nijkamp (2008) studied the attractiveness and competitiveness of the six regions of southern Italy as potential tourist destinations. The study aimed to identify the attributes in which these destinations have competitive advantages. The analysis in this study, was conducted through micro data provided by AC Nielsen SITA survey (2001), and based on a sample of 1,707 individuals who had visited at least once a region of southern Italy.

To study empirically the competitiveness of these tourist destinations, the researchers used two statistical methods: 1) a parametric non-linear statistical method, which does consist of a function of regional tourist attraction (RTA - an index, which is calculated as a function of the tourist welfare level regarding to attributes); and 2) Principal components analysis (PCA - a technique of reducing the variables number to a smaller one, uncorrelated variables called principal components). The importance of PCA is that it helps identify important factors that influence the process of tourist evaluation. 
In conclusion, the study showed that the tourists' evaluation is strongly related to additional attributes of tourism supply, mentioned as follows: information and tourist services, cultural events, quality and variety of products in stores, other hotels and accommodation, the price level and cost of living and tourists' security. While the attributes with less impact to the tourist evaluation are features like hospitality and sympathy of local residents, the cities of art and culture, the landscape, the environment and nature, which are components of the six key components proposed by Crouch and Ritchie (1999) model.

\subsection{Sinaloa, Mexico Case}

Carillo et al. (2013) in their study aimed to develop an empirical analysis of the destination competitiveness for the three main cities (Mazatlan, Culiacan and Ahome) in Sinaloa, Mexico, using Crouch and Ritchie model. The aim was that through the use of attributes could be made a comparison between the above three tourism destinations in order to identify then the most competitive destination in Sinaloa. The study used a method of alternatives ranking, known as Electra III (Roy 1990), which established a preferential model based on the information provided by the competitiveness model of Crouch and Ritchie, by ranking preferences in a descending order.

The data of this study were provided by the National Statistics Institute in Mexico (INEGI) in 2012. Crouch and Ritchie Model identified a total of 45 a number of attributes, grouped in 5 main dterminant factors of destination competitiveness. In this case the model Crouch and Ritchie (2011) was adapted and some of the attributes were modified.

Besides Electra III model, in this study the authors used a deductive algorithm method (Leyva and Aguilera, 2005) to provide an alternative to a final ranking of the alternatives (destinations). To each position of the rank is given a specific weight, and to determine the destination ranking in each case it is calculated as the sum of the production of weight to frequency of the attribute rank position. Based on this methodology, the study concluded that the most competitive destination is Mazatlan, followed by Culiacan and Ahome.

\section{Conclusions}

The evidence from these countries shows that there are different models and technics to evaluate the competitiveness of a tourism destination, but it is part of the researchers and experts' responsibility to provide the unique mixture of objectives, destination features, data availability and validity to be used in a competitiveness evaluation process.

From this reviewing article, it comes clear that there does not exist any universal model to provide the right evaluation of the destination competitiveness.

It is indispensabile that before deciding about the evaluation model or its adaptation, needs to have a good understanding of destination competitiveness related issues like as the determinants categories, measurements and statistical tools, frameworks, and models.

\section{References}

Armenski, T, Gomezelj, DO, Djurdjev, B, Deri, L \& Aleksandra, D 2011, 'Destination Competitiveness: AChallenging Process for Serbia', Journal of Studies in Human Geography, vol. 5.

Bobirca. A 'Analyzing Romania's competitiveness as a tourism destination', Advances in Hospitality and Leisure, Elsevier, vol. 4 /2008, pp 75-99, ISBN: 978-0-762-31489-8

Chambers, Leiseth, 'Destination competitiveness: An Analysis of the characteristics to differentiate all-inclusive hotels \& island destinations in the Caribbean' (2010). Rochester Institute of Technology.

Gomezelj, D.O. and Mihalič, T. (2007). 'Destination Competitiveness - Applying different models, the case of Slovenia'. Tourism Management, 29(6), 294-307 
Goffi, G. (2013). 'A Model of Tourism Destinations Competitiveness: The case of the Italian Destinatios of Excellence' en Anuario Turismo Sociedad, vol. XIV, pp.121-147.

J. Leyva, E. Fernández, 'A New Method for Group Decision Support Based on ELECTRE-III Methodol-ogy'. European Journal of Operational Research,148:1, 2003.

K.Vodeb. 'Cross-border regions as potential tourist destinations along the Slovene Croatian frontier'. Tourism and Hospitality Management, Vol. 16, No. 2, pp. 219-228, 2010.

M. Croitoru. 'Tourism Competitiveness Index - An Empirical Analysis Romania vs. Bulgaria'. Theoretical and Applied Economics, Volume XVIII (2011), No. 9(562), pp. 155-172.Sirše, J., and Mihalič, T. (1999). 'Slovenian tourism and tourism policy: A case study'. Revue de Tourisme, 3, 34-47.

P. A. Alvarez Carrillo, M. L. Santiesteban, D. A. Gastelum Chavira1, Luis A. Vega Osuna, 'An Empirical Analysis of Competitiveness on Cities of Sinaloa, Mexico with an Outranking Method', Eureka-2013. Fourth International Workshop Proceedings (C) 2013, Published by Atlantis Press156.

Sinaloa State Government, "Tourism Sector Program of the State of Sinaloa, 2011-2016", Culiacan, Sina-loa, 2012.

Wang, F. C., Hung, W. T. and Shang, J. K. 2006. 'Measuring the cost efficiency of international tourist hotels in Taiwan'. Tourism Economics.

Z. Papp, Á. Raffay. 'Factors influencing the tourism competitiveness of former socialist countries'. Human Geographies Journal of Studies and Research in Human Geography (2011) 5.2, 21-30. 